\title{
Measuring User Experience During a Web-based Survey: A Case of Back-to-Back Online Surveys
}

\author{
Paulus Insap Santosa ${ }^{\#}$ \\ \# Department of Electrical Engineering \& Information Technology, Universitas Gadjah Mada, Yogyakarta 55281, Indonesia \\ E-mail: insap@ugm.ac.id
}

\begin{abstract}
The vast availability of the Internet allows surveyors to conduct web-based survey much easier than its offline counterpart. Previous studies have been conducted to measure survey tool usability. This article reports the results of a survey on the experience of students who have just completed a survey on students' learning engagement. Students were emailed to participate on a survey about students' engagement on the learning process. After they have completed the survey, they were asked to complete another survey, a shorter one, to measure their experience during their first assignment. The second survey employed the user experience questionnaire (UEQ). The UEQ comprises 26 questions to measure six variables. There were 819 respondents who completed the first survey that 450 of them were voluntarily completed the second one. Data were analysed using UEQ data analysis. The result showed that out of 26 items, eight of them were evaluated positively and the rest were evaluated neutrally. Amongst those that were evaluated positively include friendly, good design, supportive, secure, organized, understandable, clear, and valuable.
\end{abstract}

Keywords - user experience; web-based survey; ISSLA

\section{INTRODUCTION}

A survey, as one type of research method, comes in many different methods, from door-to-door, telephone, mail, as well as online survey. It provides straightforward responses [1] although survey administrators also have to anticipate several drawbacks including response rate, cost, and administering tools.

For online survey, there are several tools or software packages that are available for both free and charged services. These tools include Google Form, Survey Monkey (http://www.surveymonkey.com), Key Survey (https://www.keysurvey.com), as well as social media, including Facebook [2]. On the other hand, researchers often develop their own survey for practical reasons, like flexibility and personalization of questionnaires presentation.

Survey designers face some challenges when they develop surveys for certain purposes. Those challenges include survey design, subjects privacy and confidentiality, and response rate [3], risk, anonymity, consent, and autonomy [4], as well as technology used to disseminate and store survey result. Previous studies on web-based survey focused on the screen/layout design, challenges, as well as cost and survey administration. This article reports the result of a web-based survey on the experience of students who just completed a longer online survey about student's learning engagement.

\section{LITERATURE REVIEW}

\section{A. Web-based Survey}

Survey is a quantitative data collecting method. A survey can be administered manually, by phone, or online, especially in the form of web-based survey (WBS). Due to the vast availability of the Internet, a WBS offers several advantages including speed and cost of data collection [5], [6]. It is also potential to reach more diverse sample amongst different populations [7]. Along with some advantages, a WBS administrator should consider several disadvantages of conducting a WBS including the need to access the Internet, thus respondents must have at least the knowledge of accessing the Internet [5] and their willingness to use computers to complete the survey [8]. Due to this situation, a WBS may face a low and selective participation [6] and sampling issue [5].

Response rates vary between different survey methods. In general, it is always better to have a high response rate. Archer (2008) [9] conducted 84 web-based surveys and found out that response rate was varied by survey types. A study conducted by [1] compared paper-based, web-based, and a mixed mode between the two. The result showed that web-based method was superior as compared to the paper- 
based. However, the mixed mode produced the highest response rate although it incurred higher cost.

As the usage of web-based survey or WBS is more prevalent, a more "standardized" survey design demands more attention. The standard should include some considerations toward screen design, question presentation, text presentation, and response format [10]. A web-based survey is by enlarge a web application, thus it is subject to several issues facing by general web design, e.g. information architecture, visual design, and navigation design [11]. Although a WBS contains limited content than those in general websites, WBS designers must consider which particular content should be present first or later.

The number of questionnaire items differs from one survey to another. It is important to consider the length of web pages to present how all items. A study about users' preference of a web page length has been done by [12]. It employed three metaphors of page length design as paper roll, textbook, and window. This study reported that users had different preference of web page length.

\section{B. User Experience}

User experience is defined as "the degree of positive or negative emotions that can be experienced by a specific user in a specific context during and after product use and that motivates for further usage" [13]. User experience is dynamic feelings that depend on internal and emotional condition of a person. This internal and external condition is likely to change during and after interaction with a product [14], [15]. There are three important components of user experience, i.e. emotions, motivation, and reflection [16]. Based on users' evaluation of their interacting with certain products, they might lifting up, reciprocate, or reject and ignore their experiences. This definition implies that the users must interact with certain products, evaluate them, and express their emotions and motivations regarding those products. User experience is also considered as the user's feeling towards a system, e.g. enjoyable, fun, frustrating, and boring [17]. The system comes in many forms including a web-based survey.

Previous studies argued that user experience comprises pragmatic and hedonic qualities, e.g. [13], [14], [18]. Pragmatic quality refers to aspect related to the usability and functionality of the products [19]. Hedonic quality refers to pleasure-producing product qualities, i.e. aspects related to emotion and motivation [18].

User experience is subjective [15]. Thus, in order to measure user experience, objective measures related are not sufficient. For example, slow loading time might be caused by the slow Internet speed rather than the web design itself. It is true that this situation may cause user frustration, but measuring user experience based in this situation alone is not sufficient. Satisfaction is a subjective component of usability that can be seen as part of user experience evaluation. However, satisfaction alone is not sufficient to measure user experience. User experience addresses other subjective qualities [20].

User experience (web and internet) showed moderating effect between perceived usefulness and future intention to visit [21]. The survey was conducted using a website that offer free information on health, nutrition, and general well- being. Web experience has also been studied to identify its important factors. Three aspects were considered as the building blocks of web experience: functionality (usability and interactivity), psychological factors (trust), and content factors (aesthetic and marketing mix) [22].

For the last few years, the usage of mobile devices, especially smartphones, is more prevalent. The smartphones utilize smaller screen size than its desktop counterpart. In order to make use of the smaller screen size just as usable as those of the desktops, a new term of web design, i.e. responsive web, was introduced. With several capabilities that a responsive web has, e.g. flexible content, fluid layout, and display capabilities, it enriches user experience [23].

Measuring user experience requires understanding of several factors that influence it directly and indirectly. Two factors have been considered by [13] as the affecting factor of user experience before, during, and after using a product, i.e. the user's basic needs and the product quality. Based on utilitarian point of view, the users' basic needs are the main reason they use certain products [18], [24]. Product quality is determined by its utility, usability and visual appeal [25], and it affects whether the users' needs are fulfilled [13].

\section{METHODOLOGY}

The online survey described in this article was actually part of a bigger online survey namely Indonesian Survey on Student Learning Activities (ISSLA). In 2015, ISSLA was conducted at Universitas Gadjah Mada (UGM). It can be considered as a pilot study before a nation wide survey that will be conducted in 2016 .

\section{A. The Design of Web-based ISSLA}

In total, there were 39 questions in ISSLA that were written in Indonesian language. Question no. 1 to question no. 17 comprised between three to 10 items. Figure 1 shows example of question no. 1 comprises 9 items. In total, there were 106 questions including 8 demographic questions. The whole questions were presented in five pages. Every page was designed to have roughly equal page length.

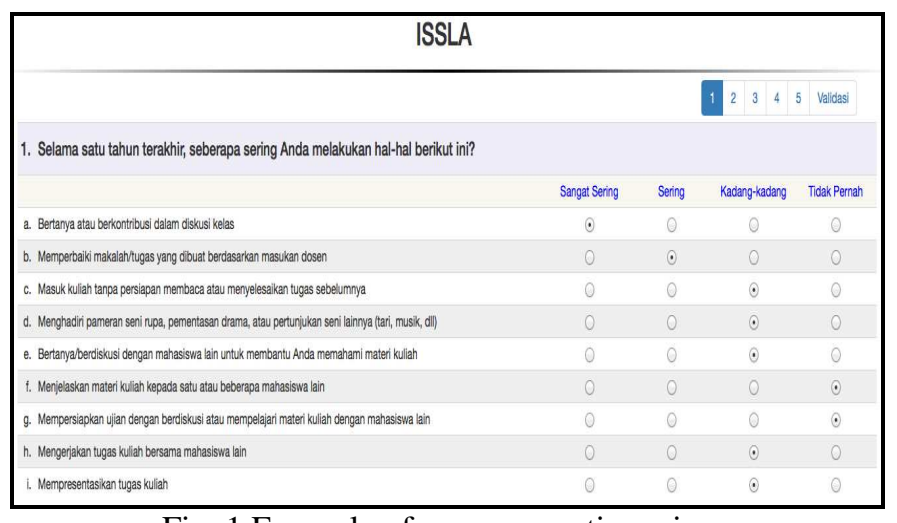

Fig. 1 Example of survey questionnaire

ISSLA was designed to follow three important pillars of web design as stated by McCracken [11], i.e. information architecture, visual design, and navigation design. However, information architecture in ISSLA was rather different as compared to other types of websites because it must follow the operational definition of each survey variable strictly. 
In term of visual design, most questions were multiplechoice questions where respondents had to choose one option among several presented options. These questions were implemented using radio buttons. Two questions were multiple-choice questions where respondents might choose one or several, even all, options; thus, they were implemented using checkbox. One question asked respondents' of their year of birth. It was implemented using dropdown list. One final question was an open-ended question that was implemented using input field.

All questions were presented in five pages. This required certain navigation scheme that allowed respondents to move freely between pages. As reported by [12], a textbook metaphor was the most preferable page length where users were able to move and jump randomly from one page to another. The ISSLA navigation was designed to follow a textbook metaphor with certain modification that prevented respondents from skipping certain page.

In term of navigation scheme, in normal situation, users were lead to complete one page after another starting from Page1 to Page5. Users were allowed to continue to the next page only after they have finished the previous page. A validation scheme was employed to assure that users complete all questions in certain page before moving to the next one. This scheme is depicted in Figure 2.a. However, in different situation, after completing certain page(s), users might want to check their previous answers. This was accomplished by clicking particular page number. After this was done, users would be brought back the last page when they decided to visit previous page.

In order to inform users of their current position, a page number indicator was provided as depicted in Figure 2.b. The visited pages were presented in blue colour, the current page is presented in white colour over blue background, and those that have not been visited were presented in grey (disabled state). After users had completed all questions, they were presented with validation page where they were able to go back to certain page to check and modify their answers. Once they were satisfied, they saved their answers, after which they were asked to answer user experience survey voluntarily. Figure 3 depicts an example of validation page.

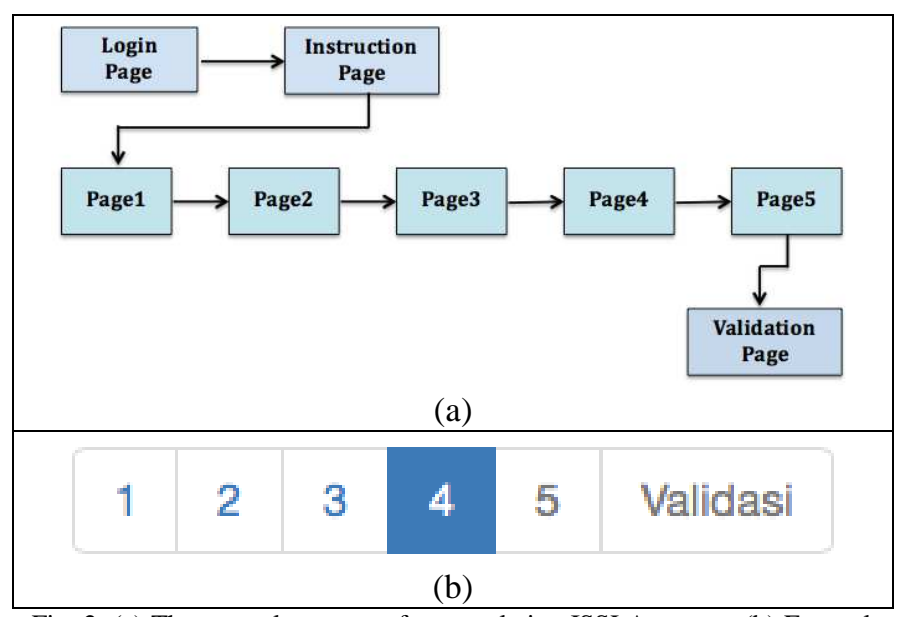

Fig. 2. (a) The normal sequence for completing ISSLA survey. (b) Example of page indicators.

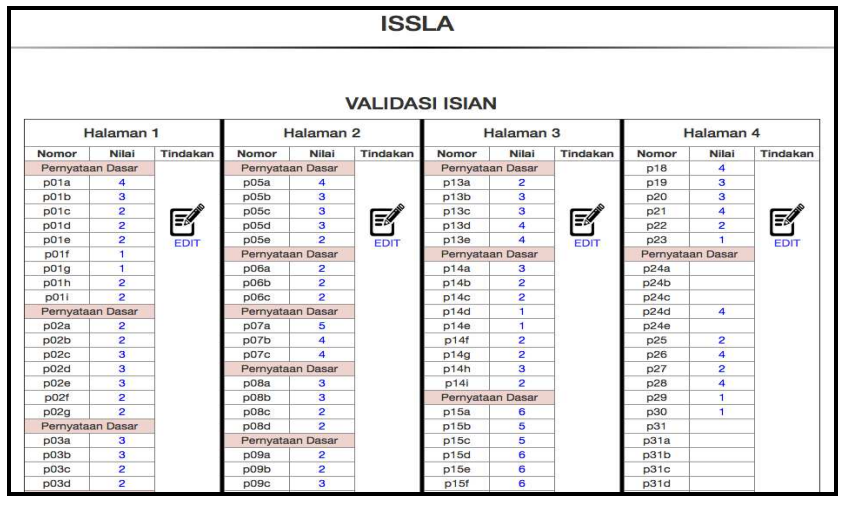

Fig.3 Example of validation page.

\section{B. Subjects and Survey Administration}

The subjects of the ISSLA were students from all departments at UGM. To comply with the purpose of ISSLA, subjects comprised students from third-semester and seventh-semester students. In total, there were 13795 subjects.

Subjects were notified by email broadcasted simultaneously from the university. Subjects were asked to participate voluntarily. Besides information asking for students' participation, the email also contained information about login credentials. These login credentials were considered important especially to make sure that those who participated in the survey were only those specified as target subjects, as well as to keep students' privacy.

ISSLA was opened 24/7 for one whole month between 15 October to 15 November 2015. Thus, subjects might participate at their convenient time. The survey was designed in such a way that subjects did not have to finish the survey in one go. They could come back at different time after they have finished answering questions in particular page(s).

\section{Measurement}

There are several measurements that can be used to measure user experience, e.g. PULSE and HEART [26]. Previous studies, e.g. [14], [13], [18], argued that user experience comprises pragmatic and hedonic qualities. To certain extend PULSE and HEART metrics is used to measure the pragmatic and hedonic quality, respectively.

PULSE comprises five measures, namely page view, uptime, latency time, seven-day active users, and earnings. In particular, according to [26], seven-day active users is a common metric for measuring user experience although it does not differentiate between new and repeating users. HEART is considered of PULSE complement. It comprises happiness, engagement, adoption, retention, and task success. Happiness is a manifestation of satisfaction, and task success is a manifestation of effectiveness and efficiency, which are two important aspects of usability. PULSE and HEART metrics have been adopted and modified to measure user experience in an online store [27]. These two metrics, under certain circumstances, was considered as the cost and benefit of conducting web activities, respectively.

Another measurement for user experience is UEQ [28]. In general, there are six variables measured in UEQ, i.e. attractiveness, perspicuity, efficiency, dependability, 
stimulation, and novelty (see Table 1). Attractiveness is measured using six items and the rest are measured using 4 items for each respective variable. Each item is measured using 7-poin Likert scale presented as a semantic differential, e.g. annoying - enjoyable, creative - dull, and conservative - innovative. In the survey, all 26 items were scrambled and the scale for each item was presented as negative to positive or positive to negative direction.

TABLE I

MEAN SCALES FOR ALL VARIABLES AND THEIR CORRESPONDING RELIABILITIES VALUE.

\begin{tabular}{|l|c|c|c|}
\hline \multicolumn{1}{|c|}{ Variable } & $\begin{array}{c}\text { Reliability } \\
\text { (Cronbach Alpha) }\end{array}$ & Mean & $\begin{array}{c}\text { Std. } \\
\text { Deviation }\end{array}$ \\
\hline Attractiveness & 0.73 & 0.601 & 0.891 \\
\hline Perspicuity & 0.68 & 0.740 & 1.096 \\
\hline Efficiency & 0.63 & 0.674 & 1.014 \\
\hline Dependability & 0.36 & 0.742 & 0.791 \\
\hline Stimulation & 0.63 & 0.422 & 1.053 \\
\hline Novelty & 0.58 & 0.022 & 1.015 \\
\hline
\end{tabular}

UEQ was originally written in German, and now available in English, Spanish, and French. Due to language differences, users may perceive certain questionnaire's item differently. The validity and reliability of English and Spanish of UEQ versions have been tested [29]. The result showed that both versions were almost identically good and comparable to well-evaluated German version. Similar study was conducted [30] to evaluate Portuguese version.

Of the six variables proposed [28], attractiveness can be considered as the outcome of the other five. Following previous studies, e.g. [13], these five variables were grouped into hedonic and pragmatic quality as stated [29] and [30]. Hedonic quality comprises stimulation and novelty, whilst pragmatic quality comprises perspicuity, efficiency, and dependability. Each of the six variables is defined as follows (modified from Cota [30]:

- Attractiveness. It's a general impression towards ISSLA website. It is used to measure whether users like or dislike ISSLA website.

- Perspicuity. It's a measure of whether it's easy to understand how to use ISSLA website and whether it's easy to get familiar with ISSLA website.

- Efficiency. It's a measure of whether it's possible to use ISSLA website fast and efficient and whether ISSLA user interface looks organized.

- Dependability. It's a measure of whether the user feel in control of the interaction and whether the interaction with ISSLA website secure and predicable.

- Stimulation. It's a measure of whether to use ISSLA website is interesting and whether the user feel motivated for a further using ISSLA website.

- Novelty. It's a measure of whether the design of ISSLA website innovative and creative and whether ISSLA website grab the user's attention.

Following previous studies, especially those of [29] and [30], all items in UEQ were translated into Indonesian language as depicted in Table 2 (written in italic). Due to the richness of each language, each item might not be translated as it supposed to be, but it was translated such that the meaning of the corresponding items was as close as possible.
TABLE II

EVALUATION OF EACH UEQ ITEM.

\begin{tabular}{|c|c|c|c|c|c|}
\hline Variable & Item \# & Left-Item & Right-Item & $\begin{array}{c}\text { Mea } \\
\mathbf{n}\end{array}$ & $\begin{array}{l}\text { Std. } \\
\text { Dev. }\end{array}$ \\
\hline Attractiveness & 1 & $\begin{array}{l}\text { annoying } \\
\text { menjengkelkan }\end{array}$ & $\begin{array}{l}\text { enjoyable } \\
\text { menyenangkan }\end{array}$ & 0.38 & 1.43 \\
\hline Attractiveness & 12 & \begin{tabular}{|l|} 
good \\
baik
\end{tabular} & $\begin{array}{l}\text { bad } \\
\text { buruk }\end{array}$ & 1.46 & 1.43 \\
\hline Attractiveness & 14 & $\begin{array}{l}\text { unlikable } \\
\text { tidak disukai }\end{array}$ & $\begin{array}{l}\text { pleasing } \\
\text { sangat disukai }\end{array}$ & 0.28 & 1.15 \\
\hline Attractiveness & 16 & $\begin{array}{l}\text { unpleasant } \\
\text { tidak nyaman }\end{array}$ & $\begin{array}{l}\text { pleasant } \\
\text { nyaman }\end{array}$ & 0.40 & 1.28 \\
\hline Attractiveness & 24 & $\begin{array}{l}\text { attractive } \\
\text { atraktif }\end{array}$ & $\begin{array}{l}\text { unattractive } \\
\text { tidak atraktif }\end{array}$ & 0.16 & 1.53 \\
\hline Attractiveness & 25 & $\begin{array}{l}\text { friendly } \\
\text { ramah }\end{array}$ & $\begin{array}{l}\text { unfriendly } \\
\text { tidak ramah }\end{array}$ & 0.94 & 1.37 \\
\hline Dependability & 8 & $\begin{array}{l}\text { unpredictable } \\
\text { susah } \\
\text { diprediksi }\end{array}$ & $\begin{array}{l}\text { predictable } \\
\text { mudah } \\
\text { diprediksi }\end{array}$ & 0.29 & 1.38 \\
\hline Dependability & 11 & \begin{tabular}{|l|} 
obstructive \\
menghambat
\end{tabular} & \begin{tabular}{|l|} 
supportive \\
mendukung \\
\end{tabular} & 1.38 & 1.26 \\
\hline Dependability & 17 & $\begin{array}{l}\text { secure } \\
\text { aman }\end{array}$ & $\begin{array}{l}\text { not secure } \\
\text { tidak aman }\end{array}$ & 0.84 & 1.45 \\
\hline Dependability & 19 & $\begin{array}{l}\text { meets } \\
\text { expectations } \\
\text { sesuai harapan }\end{array}$ & $\begin{array}{l}\text { does not meet } \\
\text { expectations } \\
\text { tidak sesuai } \\
\text { harapan }\end{array}$ & 0.46 & 1.33 \\
\hline Efficiency & 9 & $\begin{array}{l}\text { fast } \\
\text { cepat }\end{array}$ & $\begin{array}{l}\text { slow } \\
\text { lambat }\end{array}$ & 0.53 & 1.54 \\
\hline Efficiency & 20 & $\begin{array}{l}\text { inefficient } \\
\text { tidak efisien }\end{array}$ & $\begin{array}{l}\text { efficient } \\
\text { efisien }\end{array}$ & 0.54 & 1.39 \\
\hline Efficiency & 22 & $\begin{array}{l}\text { impractical } \\
\text { tidak praktis }\end{array}$ & $\begin{array}{l}\text { practical } \\
\text { praktis }\end{array}$ & 0.57 & 1.49 \\
\hline Efficiency & 23 & $\begin{array}{l}\text { organized } \\
\text { terorganisir }\end{array}$ & $\begin{array}{l}\text { cluttered } \\
\text { tersebar }\end{array}$ & 1.06 & 1.46 \\
\hline Novelty & 3 & $\begin{array}{l}\text { creative } \\
\text { kreatif }\end{array}$ & $\begin{array}{l}\text { dull } \\
\text { menjemukan }\end{array}$ & -0.05 & 1.72 \\
\hline Novelty & 10 & $\begin{array}{l}\text { inventive } \\
\text { inventif }\end{array}$ & $\begin{array}{l}\text { conventional } \\
\text { konvensional }\end{array}$ & 0.14 & 1.41 \\
\hline Novelty & 15 & $\begin{array}{l}\text { usual } \\
\text { biasa }\end{array}$ & $\begin{array}{l}\text { leading edge } \\
\text { istimewa }\end{array}$ & -0.36 & 1.52 \\
\hline Novelty & 26 & $\begin{array}{l}\text { conservative } \\
\text { konservatif }\end{array}$ & $\begin{array}{l}\text { innovative } \\
\text { inovatif } \\
\end{array}$ & 0.36 & 1.43 \\
\hline Perspicuity & 2 & $\begin{array}{l}\text { not } \\
\text { understandable } \\
\text { susah dipahami }\end{array}$ & $\begin{array}{l}\text { understandable } \\
\text { mudah } \\
\text { dipahami }\end{array}$ & 0.85 & 1.54 \\
\hline Perspicuity & 4 & $\begin{array}{l}\text { easy to learn } \\
\text { mudah } \\
\text { dipelajari }\end{array}$ & $\begin{array}{l}\text { difficult to } \\
\text { learn } \\
\text { susah } \\
\text { dipelajari } \\
\end{array}$ & 0.77 & 1.52 \\
\hline Perspicuity & 13 & $\begin{array}{l}\text { complicated } \\
\text { rumit }\end{array}$ & $\begin{array}{l}\text { easy } \\
\text { mudah }\end{array}$ & 0.50 & 1.51 \\
\hline Perspicuity & 21 & $\begin{array}{l}\text { clear } \\
\text { jelas }\end{array}$ & $\begin{array}{l}\text { confusing } \\
\text { membingungkan }\end{array}$ & 0.84 & 1.55 \\
\hline Stimulation & 5 & $\begin{array}{l}\text { valuable } \\
\text { bermanfaat }\end{array}$ & $\begin{array}{l}\text { inferior } \\
\text { tidak } \\
\text { bermanfaat } \\
\end{array}$ & 1.10 & 1.64 \\
\hline Stimulation & 6 & \begin{tabular}{|l|} 
boring \\
membosankan
\end{tabular} & $\begin{array}{l}\text { exciting } \\
\text { mengasyikkan }\end{array}$ & -0.17 & 1.45 \\
\hline Stimulation & 7 & $\begin{array}{l}\text { not interesting } \\
\text { tidak menarik }\end{array}$ & $\begin{array}{l}\text { interesting } \\
\text { menarik }\end{array}$ & 0.08 & 1.51 \\
\hline Stimulation & 18 & $\begin{array}{l}\text { motivating } \\
\text { memotivasi }\end{array}$ & $\begin{array}{l}\text { demotivating } \\
\text { tidak } \\
\text { memotivasi } \\
\end{array}$ & 0.68 & 1.52 \\
\hline
\end{tabular}

Words written in italic are Indonesian translation.

\section{DATA ANALYSIS AND DISCUSSION}

It was said in the previous section that the online UEQ was preceded by a web-based survey to measure students' engagement in their learning process (ISSLA). Thus, basically the online UEQ was to measure the students' 
experience during completing ISSLA. The total number of invitation sent was 13795. After a month, the number of students completed ISSLA was 819. Amongst those who completed ISSLA, 450 were voluntarily completed UEQ. Thus, the data analysis was done based on 450 subjects.

The calculation of some important measures, e.g. reliability, confidence level, and overall results has been provided in an Excel file. After the data were copied into a 'Data' tab, all the needed calculations were performed.

UEQ [28] stated that the mean of each variable/item ranging from -3 to +3 . The value of -3 means the most extreme negative evaluation and +3 means the most extreme positive evaluation. The mean value between -0.8 and +8 is considered as neutral evaluation, the mean value $>0.8$ is considered as positive evaluation, and the mean value $<-0.8$ is considered as negative evaluation. Table 1 depicts the mean scales for all the main variables with their corresponding reliabilities. Table 2 depicts the mean scale for each item corresponds to its main variable.

According to the above 'rules', all variables were evaluated neutral (Table 1). Further observation of these results shows that all variables, except novelty, there are one or two items that were evaluated positively, i.e. attractiveness (good and friendly), perspicuity (understandable and clear), efficiency (organized), dependable (supportive, secure), and stimulation (valuable). Thus, referring to [29], [30], hedonic quality was evaluated as valuable and pragmatic quality was evaluated as understandable, clear, organized, supportive, and secure. These evaluations provide the final evaluation of the ISSLA website as good and friendly.

The above results indicate that very few of ISSLA web design elements abled to evoke emotions. This is understandable because ISSLA was not designed to explore respondents' feelings. Unlike the online shopping or news portals sites that were designed to influence user's emotions that may result in transaction or revisit, the content of ISSLA was more serious in nature. On the other hand, most respondents did not feel any 'wow' factor related to ISSLA design that abled to stir up respondents' feelings. This can be seen from the fact that novelty was evaluated neutral.

On the other hand, from the pragmatic elements of quality, all three variables were evaluated positively perspicuity, dependable, and efficiency. According to webster.com, perspicuity is an adjective that explains how people understand certain things as a result of the clarity and precision of presentation of those things. Two items of perspicuity were evaluated positively, i.e. understand and clear. Positive evaluation of the two items in perspicuity was due to the fact that the words and their structures on each questionnaire were chosen such that they were easy to understand.

Efficiency was evaluated positively as organized. The ISSLA web was designed to follow certain rule, especially those from [11]. Wording, page length, web elements, and navigation were chosen and designed very carefully that respondents evaluated them as organized.

Two items in dependable were evaluated positively, i.e. supportive and secure. Questionnaires in ISSLA were presented into five pages. Each page was designed to have roughly equal page length. To ease navigation, each page was equipped with page indicator. This page indicator has two functions. Firstly, it informs the current page where respondents are working on. Secondly, it informs how far respondents have completed the survey. These to functions contributed to the supportive aspect of ISSLA.

The second positive evaluation of dependable was secure. Respondents felt that ISSLA was secure. This was due to the fact that they had to login to ISSLA before they were able to complete the survey. By using this mechanism, only those who have been sent login data were able to participate to ISSLA.

\section{CONCLUSIONS}

A web-based survey to measure user experience during a bigger web-based survey has been conducted. Based on UEQ, 5 variables were measured between neutral and positive. Only one variable was measured neutral. To be more precise, items that were measured positively were attractiveness (good and friendly), perspicuity (understandable and clear), efficiency (organized), dependable (supportive, secure), and stimulation (valuable). While all items in novelty were measured neutral. This means that the design of ISSLA website is nothing extra ordinary. It can be concluded that the design of ISSLA website has some positive measures, i.e. friendly, clear, organized, and secure.

\section{REFERENCES}

[1] C. Greenlaw and S. Brown-Welty, "A Comparison of Web-Based and Paper-Based Survey Methods," Eval. Rev., vol. 33, no. 5, pp. 464-480, 2009.

[2] D. E. Ramo and J. J. Prochaska, "Broad Reach and Targeted Recruitment Using Facebook for an Online Survey of Young Adult Substance Use,” J. Med. Internet Res., vol. 14, no. 1, pp. 1-13, 2011.

[3] D. Andrews, B. Nonnecke, and J. Preece, "Conducting Research on the Internet: Online Survey Design , Development and Implementation Guidelines," Int. J. Hum. Comput. Interact., vol. 16, pp. 185-210, 2003.

[4] E. a. Buchanan and E. E. Hvizdak, "Online Survey Tools: Ethical and Methodological Concerns of Human Research Ethics Committees," J. Empir. Res. Hum. Res. Ethics, vol. 4, pp. 37-48, 2009.

[5] K. B. Wright, "Researching Internet-Based Populations: Advantages and Disadvantages of Online Survey Research, Online Questionnaire Authoring Software Packages, and Web Survey Services," J. Comput. Commun., vol. 10, no. 2005, p. 0, 2005.

[6] E. Heiervang and R. Goodman, "Advantages and limitations of webbased surveys: evidence from a child mental health survey," Soc. Psychiatry Psychiatr. Epidemiol., vol. 46, no. 1, pp. 69-76, 2011.

[7] H. Matsuo, K. P. Mcintyre, T. Tomazic, and B. Katz, "The Online Survey: Its contributions and potential problems," Proc. Jt. Stat. Meet. Am. Stat. Assoc., pp. 3998-4000, 2005.

[8] M. Carbonaro and J. Bainbridge, "Design and development of a process for Web-based survey research," Alberta J. Educ. Res., vol. 46, no. 4, pp. 392-394, 2000.

[9] T. M. Archer, "Response rates to expect from web-based surveys and what to do about it," J. Ext., vol. 46, no. 3, pp. 1-6, 2008.

[10] S. Crawford, S. E. McCabe, and D. Pope, "Applying Web-based Survey Design Standards," J. Prev. Interv. Community, vol. 29, no. 1/2, pp. 43-66, 2005.

[11] D. D. McCracken, R. J. Wolfe, and J. M. Spool, User-Centered Web Site Development: A Human-Computer Interaction Approach. Prentice Hall, 2004.

[12] P. I. Santosa, "User' s Preference of Web Page Length," Int. J. Res. Rev. Comput. Sci., vol. 2, no. 1, pp. 180-185, 2011.

[13] K. Schulze and H. Krömker, "A Framework to Measure User Experience of Interactive Online Products," in Proceedings of Measuring Behavior, 2010, vol. 2010, pp. 261-264. 
[14] M. Hassenzahl, "User experience (UX): Towards an experiential perspective on product quality," in Proceedings of the 20th International Conference of the Association Francophone d'Interaction Homme-Machine on - IHM '08, 2008, p. 11.

[15] E. L.-C. Law, V. Roto, M. Hassenzahl, A. P O. S. Vermeeren, and J. Kort, "Understanding, scoping and defining user experience," in Proceedings of the 27th international conference on Human factors in computing systems - CHI 09, 2009, pp. 719-728

[16] K. Battarbee and I. Koskinen, "Co-Experience: User Experience as Interaction," CoDesign, vol. 1, no. 1, pp. 5-18, 2005.

[17] P. Ramakrisnan, A. Jaafar, and N. F. B. M. Yatim, "Emotional user experiences in discussion board design: Kansei methodological triangulation approach," in 2012 International Conference on Computer and Information Science, ICCIS 2012 - A Conference of World Engineering, Science and Technology Congress, ESTCON 2012 - Conference Proceedings, 2012, vol. 2, pp. 1073-1077.

[18] E. Bridges and R. Florsheim, "Hedonic and utilitarian shopping goals: The online experience," J. Bus. Res., vol. 61, no. 4, pp. 309-314, Apr. 2008

[19] P. van Schaik and J. Ling, "Modelling user experience with web sites: Usability, hedonic value, beauty and goodness," Interact. Comput., vol. 20, no. 3, pp. 419-432, May 2008.

[20] A. P. O. S. Vermeeren, E. L. Law, and V. Roto, "User Experience Evaluation Methods: Current State and Development Needs," in Proceedings of NordiCHI, 2010, pp. 521-530.

[21] J. A. Castañeda, F. Muñoz-Leiva, and T. Luque, "Web Acceptance Model (WAM): Moderating effects of user experience," Inf. Manag., vol. 44, no. 4, pp. 384-396, Jun. 2007.
[22] E. Constantinides, "Influencing the online consumer's behavior: the Web experience," Internet Res., vol. 14, no. 2, pp. 111-126, 2004.

[23] B. S. Gardner, "Responsive Web Design: Enriching the User Experience," Sigma, vol. 11, no. 1, pp. 13-19, 2011.

[24] M. Hassenzahl, K. Eckoldt, and M. T. Thielsch, User Experience und Experience Design - Konzepte und Herausforderungen. Fraunhofer Verlag, 2009.

[25] S. Mahlke, "User Experience of Interaction with Technical Systems," 2008

[26] K. Rodden, H. Hutchinson, and X. Fu, "Measuring the User Experience on a Large Scale: User-Centered Metrics for Web Applications," in Proceedings of CHI, 2010, pp. 10-15.

[27] P. I. Santosa, "Measuring User Experience in An Online Store Using PULSE and HEART Metrics," J. Ilm. Kursor (Terakreditasi Dikti), vol. 7, no. 3, pp. 145-153, 2014

[28] B. Laugwitz, T. Held, and M. Schrepp, "Construction and evaluation of a user experience questionnaire," HCI Usability Educ. Work, vol. 4,pp. 63-76, 2008

[29] M. Rauschenberger, M. Schrepp, M. Perez-Cota, S. Olschner, and J. Thomaschewski, "Efficient Measurement of the User Experience of Interactive Products. How to use the User Experience Questionnaire (UEQ).Example: Spanish Language Version," Int. J. Interact. Multimed. Artif. Intell., vol. 2, no. 1, pp. 39-45, 2013.

[30] M. P. Cota, J. Thomaschewski, M. Schrepp, and R. Gonçalves, "Efficient Measurement of the User Experience. A Portuguese Version," Procedia Comput. Sci., vol. 27, no. 34, pp. 491-498, 2014. 